\title{
A time to change the Fiji general elections of 1999
}

\author{
Brij V. Lal
}

The 1990s has been a decade of unexpected political change in Fiji, confounding conventional wisdom and supposed understandings about power sharing arrangements in that troubled country. For the sheer momentum and unpredictability of events, it rivals the 1960s, Fiji's decade of decolonisation, a time of violence-threatening industrial strikes, keenly contested elections and by-elections, and tense conferences about constitutional systems suited to Fiji's multiethnic society. The 1990s too, Fiji's decade of progressive political democratisation, has had its tension and turbulence and false starts and extended detours as its people grappled with the unsettling aftermath of the coups and struggled to devise a constitutional order suited to its situation. ${ }^{1}$

The decade began on a divided note, as the architects of the coups of 1987 attempted to frame a Constitution to entrench Fijian political control within a nominally democratic framework. That goal was enshrined in an Interim Constitution promulgated on $25 \mathrm{July} 1990$. Contested and opposed by Indo-Fijians and others marginalised by it, and denounced by the international community affronted by its disregard for universal human rights conventions, the Constitution was reviewed by an independent commission five years later. The commission recommended a more inclusive, non-racial system of representation while protecting the legitimate interests and concerns of the different communities. ${ }^{2}$ Two years later, most of the commission's recommendations, except for the reversal of the proportion of open and reserved seats, were incorporated in a new Constitution approved unanimously by parliament and, more significantly, blessed by the all-powerful Great Council of Chiefs. Within ten years, Fiji had traveled the gamut from coup to constitutionalism like few other countries.

In May 1999, Fiji went to the polls under the revised Constitution. 'Fiji's general elections now under way are expected to see the three-party 
coalition led by outgoing prime minister Sitiveni Rabuka emerge as the largest block in the new House of Representatives', wrote one respected observer after voting began, echoing virtually every observer of the Fijian scene. The report went on: "The coalition conducted the most coherent campaign, making the most of the advantages of incumbency, and Rabuka was clearly the dominant figure in campaigning. ${ }^{\prime 3}$ The Fiji voters delivered a dramatically different verdict, electing by a landslide a newly formed, fractious 'People's Coalition' consisting of the Fiji Labour Party, the Party of National Unity (PANU) and the Fijian Association Party (FAP), with Labour winning 37 of the 71 seats in the House of Representatives, enough to govern alone. The other coalition of the Soqosoqo ni Vakavulewa ni Taukei (SVT), the National Federation Party (NFP) and the United General Party (UGP), suffered a massive defeat, with the NFP losing every seat, and the SVT winning only 8 . The shock caused by this earthquake will be felt for a long time.

Ironies abound. Against all odds and all expectations, an Indo-Fijian, Mahendra Pal Chaudhry, was appointed prime minister-a prospect that would have appeared implausible just a few days earlier-and in coalition with a political party, the Fijian Association, whose overtures for political support to form a government in 1992 Chaudhry had rebuffed. Ratu Sir Kamisese Mara, whom Chaudhry had regarded as the evil genius behind the country's recent political troubles, was now hailed as an ally, a statesman providing sage advice to an inexperienced, hastily cobbled together administration representing divergent agendas and speaking with discordant voices. On the other side of the divide, NFP's Jai Ram Reddy had joined hands with SVT leader Rabuka whom he had refused to support-but whom Chaudhry had supported-for prime minister a few years back.

The two dominant figures of contemporary politics, widely praised for their leadership in the Constitution review, became generals without armies. Rabuka resigned from parliament to become (a commoner) chairman of the Great Council of Chiefs and the Commonwealth Secretary General's peace envoy to Solomon Islands. From coup-maker to international peace negotiator: it was a remarkable journey. For Reddy, also widely respected for his contribution to the country's healing, the results were a fateful replay of history. His party, under A.D. Patel, had played a leading role in Fiji's independence struggle but was consigned to the wilderness of the opposition benches for a generation. Now once again, he and his party were dealt a crushing blow and destined for a place on the political margins after helping deliver the best Constitution Fiji ever had and laying the foundations of a truly multiracial democracy. Parties which had played a marginal or negligible role in formulating the new Constitution were now poised to enjoy its benefits. The vanquished of 1987 had emerged victorious in 1999. 
The conduct of the campaign and its outcome were determined by the provisions of the new Constitution. The first important feature was the provision for electing members of parliament, in particular the House of Representatives (the Senate being an appointed body). Of the 71 seats in the House, 46 are elected on a reserved, communal basis, with 23 contested by Fijian communal candidates, 19 by Indo-Fijians, 3 by General Electors and 1 by the Council of Rotuma. For these seats, the candidates as well as the voters belong to the same ethnic category. The remaining 25 are open (common roll) seats, with ethnic restriction for neither voters nor candidates. These open seats are an innovation for Fiji, designed to lead gradually but decisively away from communal to non-racial politics. Under the 1990 Constitution, all seats were communally reserved for the three ethnic communities ( 37 for Fijians, 27 for Indo-Fijians, and 5 for General Electors). The 1970 (independence) Constitution had a curious mixture of communal and cross-voting national seats where the ethnicity of the candidates was specified but all voted for them. ${ }^{4}$ The way in which the open seats were contested proved crucial to the outcome in some constituencies and helped determine the overall result.

The 1997 Constitution also provided for a new alternative, or preferential, voting (AV) system, to replace the archaic first-past-the-post system inherited at independence. The AV was the system recommended by the Constitution Review Commission (Fiji Constitution Review Commission 1996:304-30). The ballot paper required voters to vote either above the line, accepting the party's allocation of preferences, or below the line, where they could rank the candidates themselves. Most voted above the line, and this had an important bearing on the outcome of the election.

The third feature of the Constitution which affected the outcome was the mandatory provision for power-sharing, entitling any political party with more than 10 per cent of seats in the lower house to a place in cabinet (in proportion with its percentage of seats). The party with the most number of seats provides the prime minister, who allocates portfolios in cabinet. Because of this provision for a multiparty cabinet, the parties in the winning People's Coalition formed only a loose coalition among themselves, leaving the details of power-sharing and leadership to be decided after the elections. This tactic gave them flexibility and internal leverage. The NFP, SVT and UGP, on the other hand, formed a binding pre-election coalition in a more conventional mould.

The campaign was the most relaxed in living memory. Trading preferences with other parties dampened what would have been a fiery campaign. For once, race was relegated to the background because both coalitions were multiracial. The constitutional provision for mandatory power-sharing also made political parties wary of being too aggressive towards each other because of the possibility of working together in cabinet. 
The multi-party cabinet concept also erased the winner-take-all mentality. The long and difficult negotiations preceding the promulgation of the new Constitution had created goodwill and understanding and cross-cultural friendship among candidates facing each other in the election. The fact that the Constitution had been approved unanimously by the parliament, endorsed by the Great Council of Chiefs (also known as the Bose Levu Vakaturaga or BLV), and warmly welcomed by the international community, also had a calming effect.

The fear that the rights of indigenous Fijians could be eroded if a nonFijian ruled, had often been used to mobilise opposition to that prospect, as had happened in 1987. People were generally ignorant of the way in which their rights and interests were protected in the Constitution. That was no longer true. The new Constitution was home-grown, devised in a transparent manner after wide consultation and in full glare of national publicity and international scrutiny. This was not the case with the 1970 Constitution which was negotiated in secrecy, approved in London and never subjected to a referendum. The 1990 Constitution was also promulgated by presidential decree with no popular participation.

For the first time, the legitimate needs and concerns of all communities were protected in a manner broadly acceptable them. The Great Council of Chiefs, whose constitutional role was recognised, could veto legislation that touched issues of concern to the Fijian people; it nominated both the president and the vice president; the ownership of Fijian land according to Fijian custom was recognised along with their and the Rotuman people's right to governance through separate administrative system. The Compact, a set of principles which all governments are enjoined to observe, provides that where the interests of the different communities were in conflict, 'the paramountcy of Fijian interests as a protective principle continues to apply, so as to ensure that the interests of the Fijian community are not subordinated to the interests of any other community'. And all communities were assured that affirmative action and social justice programs would be 'based on an allocation of resources broadly acceptable to all communities'. Clarifying the principles and procedures of governance helped greatly in allaying fears and doubts.

\section{Political parties}

Twenty-one political parties contested the election. ${ }^{5}$ Many were obscure in origin and purpose and insignificant in their impact. If known at all, this reflected their entertainment value rather than their vision. Among these were the Natural Law Party, the Coalition of Independent Nationals (COIN) Party, the Viti Levu Dynamic Multiracial Democratic Party, the Tawavanua Party, the National Democratic Party, and the Farmers and General Workers 
Coalition Party. The main actors were in the two coalitions, and in the Christian Democratic Alliance, which emerged on the eve of the campaign.

\section{SVT/NFP/UGP coalition}

This was a predictable coalition of three self-described mainstream parties representing the three main ethnic communities, standing on the basis of a firm pre-election agreement about power-sharing. The members of the coalition had worked together, and they promised to continue their dialogue and consensus. Sitiveni Rabuka and Jai Ram Reddy, leading the two main parties, had contributed significantly in securing the approval of the new Constitution in parliament. Rabuka had invited Reddy to address the Great Council of Chiefs to seek their blessing of the Constitution. The two had set up a joint parliamentary committee to resolve the complex issue of expiring leases under the Agricultural Landlord and Tenant Act (ALTA). ${ }^{6}$ Rabuka and Reddy, so different from each other in training and temperament-one a soldier, open and intuitive; the other a lawyer, reserved and cautious - enjoyed a remarkable personal rapport, which they promised to translate into continuing cooperation.

Both leaders extolled the virtues of a pre-election coalition. Reddy said that

a coalition that shares common goals, ideas and policies is more likely to succeed than a post-election multiparty government of hitherto mutually hostile forces. [Another] compelling case is the need to bring together the different racial groups as partners in the electoral process in order to reduce communal tensions that have historically characterised our elections of the past. We want to put an end to the long years of political rivalry between our different communities and usher in a new era of political cooperation-consistent with the aims and objectives of the Constitution. The valuable experience we have acquired during the making of the new Constitution and the immense goodwill that has been shown by the Fijian people can be made the basis for solving many of our difficult problems such as ALTA, crime, unemployment, health and education. They cannot be solved through confrontation but by working together (Daily Post 26 March 1999).

Each party had its own separate history. The SVT was formed in 1990, with the blessing of the Great Council of Chiefs, as the main Fijian party representing the Fijian community. However, the dream of Fijian political unity under the umbrella of a single party was short-lived (Lal 1998). The SVT was wrecked by internal dissension and rival ambitions among its leaders which brought about its downfall in 1993. Influential chiefs distanced themselves from the party they had blessed, Rabuka's leadership 
was questioned and ridiculed within his own party, and rival parties were formed to challenge the SVT's authority among Fijians-the Great Council of Chiefs' nominal sponsorship notwithstanding. Deserted by leading chiefs and former supporters, including members of the powerful Methodist Church, the SVT was not what it had been in the early 1990s, but it was still the largest party in parliament.

The SVT's main partner, the National Federation Party, was the oldest party in Fiji. Formed in 1963 to combat the Colonial Sugar Refining Company as well as the colonial raj, it had been in the vanguard of Fiji's decolonisation movement. After independence, the party was beset by bitter leadership battles and rampant factionalism. Jai Ram Reddy healed the wounds and restored some of its credibility, but its role as the sole voice of the Indo-Fijian community was effectively challenged by the Fiji Labour Party, formed in 1985 to combat the World Bank-inspired economic policies of the Alliance government. The two coalesced to win the 1987 election, but their month-long government was overthrown in a military coup.? They parted company over a range of essentially tactical issues in the early 1990s, and became bitter rivals as the election approached.

The third leg of the coalition was the United Generals Party (UGP), which emerged from factions within the small General Elector community of Europeans, Part-Europeans, Pacific Islanders and others of non-Fijian and non-Indian ancestry. The 'Generals' were once a powerful influence, always over-represented, but their parliamentary seats has been gradually shrunk over the years, from eight under the 1970 Constitution to five in 1990 and three in 1997. This shrinkage intensified competition among aspirants. Indeed, much of the dispute centered on the selection of candidates. ${ }^{8}$

The coalition agreement, signed by Rabuka, Reddy and UGP leader David Pickering, provided that the leader of the SVT, whoever it might be, would be the coalition's nominee for prime minister, while the NFP leader would become deputy prime minister, with the UGP being guaranteed a cabinet seat. Second, the parties agreed to share the 25 open seats, with SVT getting 14 and NFP 11. The two parties agreed to give their first preference to each other's designated candidates for the open seats, and not field parallel candidates or support independents or other candidates. The coalition would last until the next election, with the parties working together as coalition partners even if one party won enough seats to govern alone. Finally, the agreement provided for regular consultations to develop policy or resolve difficulties, but agreed to 'respect particular Party positions in agreed areas where special group interests may be affected'.

This escape clause was necessary because there were areas where the two parties had diametrically opposed positions. The privatisation of public assets was one, and it highlights the difficulty for the coalition in mounting an effective campaign as a unit. What one partner advertised as a major 
achievement, the other saw as a public policy disaster. The SVT government had sold 49 per cent of Amalgamated Telecom Holdings Limited for F\$253 million to the Fiji National Provident Fund, and 51 per cent of the National Bank of Fiji to Colonial Mutual Insurance Company for F\$9.5 million, ostensibly to promote competition in the private sector. It had also sold 17 per cent of Air Pacific for F $\$ 26.8$ million to foreign airlines 'to strengthen the airline's international network and [increase] tourist arrivals', and 51 per cent of the Government Shipyard for F\$3.2 million to improve its 'competitiveness and [win] international orders' (Ministry of National Planning Information Brochure 1998). These sales, the government argued, would free resources for growth in the private sector and enable it to 'focus more on improving the efficiency of its operations in the priority sectors, that is, core and essential services'. The NFP, on other hand, opposed privatisation of state enterprises which were yielding high returns or covered strategic resources, such as the international airport and shipping facilities, or those which were undertaken purely to fund recurrent fiscal deficits. It supported only those privatisation efforts in which the state had no legitimate economic interests or which were unprofitable or relied on permanent grants and subsidies. The People's Coalition was unambiguous in its opposition: 'strategic utilities such as water, electricity, telecommunication and civil aviation facilities must remain in public hands as viable units'.

Another issue dividing the parties was the status of state land. There are two types of state (formerly crown) land: Schedule A (52,513 ha) refers to land owned by landowning mataqali (clans) deemed to have become extinct by the time of Cession in 1874; and Schedule B (43,113 ha) refers to land which was unoccupied and had no claimants when the Native Lands Commission met. These lands were managed by the state. In the early 1990s, facing pressure from landless Fijians, the government devised a Bill to return these lands to Fijians and their management was transferred to the Native Land Trust Board, which also manages native land on behalf of Fijian landlords. The NFP criticised the government's proposal. It also opposed the policy of purchasing freehold land and giving it to the Fijians. It had been particularly vocal in denouncing the setting up of the Viti Corps, a government initiative to provide agricultural training to Fijian youth on a freehold property it had purchased for F\$7 million. Other areas of disagreement included strategies for creating employment, strengthening economic growth and poverty alleviation.

The coalition agreement compromised both parties. The SVT could not highlight its pro-Fijian policies for fear of alienating supporters of its coalition partner, while the NFP had to soften its public opposition to the government. They were caught on the horns of a dilemma. As ethnic parties they were expected to champion the sectional interests of their communities. And yet, as parties which had worked together to fashion a new 
Constitution and lay the foundations of a new multiracialism, they could not afford to adopt an 'ethnicist' position which might have sharpened their appeal among supporters, but in the process hurt the larger cause of reconciliation. The two parties were not standing on the joint record; they were standing on their promise to work together in future. It was a critical distinction which was lost on the electorate.

\section{The People's Coalition}

The People's Coalition was the other main multiracial coalition. Unlike the SVT/NFP/UGP Coalition, it was loosely structured, and details of the agreement and internal understandings about power sharing were never released to the public. The coalition consisted of the Fiji Labour Party, the Party of National Unity and the Fijian Association. Each had its own history and agenda, but they were united by one common, overriding ambition: to remove Rabuka from power and (for Labour) to remove Reddy and the National Federation Party as the party of the Indo-Fijians.

The Fiji Labour Party was formed in 1985 as a multiracial party backed by the powerful trade unions. Dr Timoci Bavadra, an indigenous Fijian medical doctor, was its founding president and leader, with the powerful Fiji Public Servants Association leader Mahendra Chaudhry as its mastermind and general secretary. Labour won the 1987 election in coalition with the NFP, only to be deposed in a coup a month later. The partnership did not last long, the rift erupting into a bitter disagreement over participation in the 1992 election. NFP participated, while Labour decided not to, until the last minute. ${ }^{9}$ Labour's support for Sitiveni Rabuka as prime minister following the 1992 elections, drove the two parties further apart. Although they returned to make a joint submission to the Constitution Review Commission, the rift was widening. By the mid 1990s, Labour was a shadow of its earlier self, with most of its founding members having left for other parties, including many Fijians. By the time of the election, it had enticed some back. The FLP, although supported predominantly by IndoFijians, had continued to field Fijian candidates in previous elections, and kept nurturing its support base among workers and farmers and the trade unions.

The spectacularly misnamed western Viti Levu-based Party of National Unity (PANU) was the brainchild of Apisai Tora, the quintessential political chameleon. In a political career spanning nearly four decades, Tora had been a member of nearly every political party in Fiji, beginning with the Western Democratic Party in 1964, progressing to the National Democratic Party, the National Federation Party, the Alliance, the All National Congress, and the Fijian Association Party. He had been a founding member of the nationalist Taukei Movement, and an enthusiastic supporter of the coups. But throughout his tortuous-not to say tortured-career, he had been a 
fierce champion of western Fijian interests which, he argued, had been neglected in a government dominated by chiefs of the eastern establishment. PANU was Tora's latest vehicle to redress the longstanding grievance of the western Fijians and to gain for them an appropriate place in the Fijian sun. In the West were concentrated all the nation's wealth-generating industries: sugar, tourism, gold and pine as well as the international airport and the hydroelectric power stations, Tora argued, and he wanted a commensurate share of national power.

PANU had the blessing of prominent western chiefs, including the Tui Vuda - the paramount chief of western Fiji and vice president-Ratu Josefa Iloilo, Tui Nawaka Ratu Apisai Naevo, Tui Sabeto Ratu Kaliova Mataitoga, Tui Vitogo Ratu Josefa Sovasova, and Marama na Tui Ba Adi Sainimili Cagilaba. The list is impressive, but the chiefs' support did not carry as much influence as before (The Review May 1998). Tora first broached a coalition with the SVT, and wanted a seat-sharing arrangement which would recognise his influence in the west. He was rebuffed by western Fijian members of the SVT, especially Isimeli Bose and Ratu Etuate Tavai. Tora, they felt, was a spent force, his reputation for integrity and probity tainted by his impressive record of political bed-hopping. Moreover, the seat-sharing formula sought by Tora would have ended SVT's reign in western Viti Levu, a prospect no serious party could countenance. Tora then turned to Labour, which responded favourably. It was a coalition of convenience. Labour gave Tora a wider platform upon which, by relying on his cunning, he no doubt hoped to enlarge his own agenda. Tora promised Labour western Fijian support and assistance in resolving the issue of the expiring leases. The land issue was serious. On the eve of the election, Ba chiefs, who command the largest province, wanted 87 per cent of the leases not to be renewed (34,634 out of 39,725 ha) and in Sabeto, Nawaka, Nadi and Vuda, the chiefs wanted 92 per cent of the leases not to be renewed (12,728 out of 13,704 ha). Tora held-or seemed to holdpowerful cards.

The Fijian Association was the third member of the People's Coalition. It was formed in the early 1990s by Fijians opposed to Rabuka, ridiculing his leadership and attacking his moral character. Its founder was Josefata Kamikamica, an affable, mild-mannered but politically naive long-term head of the Native Land Trust Board and a member of the Mara-led postcoup Interim Administration (in which he had served as finance minister). He unsuccessfully challenged Rabuka for prime minister in 1992, but failed to get elected in 1994 and in later by-elections. After his death in 1998, the Fijian Association was led by Adi Kuini Bavadra Speed, the re-married widow of the founding Labour leader and herself onetime leader of the Fiji Labour Party and president of the All National Congress. The party's social philosophy was broadly similar to Labour's (Daily Post April 1999). In fact, 
nearly all its leading Fijian candidates were former members or friends of the Labour Party. But the party also contained a strange assortment of political refugees from other parties, with their own agendas and ambitions, united by the overriding desire to see Rabuka defeated. Sometimes the Fijian Association gave the impression of having a 'schizophrenic personality': ${ }^{10}$ of saying one thing and doing another. One of its parliamentarians, Viliame Cavubati, was standing for the SVT while another, Dr Fereti Dewa, missed out on selection and launched a scathing attack on the party leaders. Its parliamentary leader, the ever unpredictable Ratu Finau Mara, had left politics for a diplomatic career.

The People's Coalition had few common understandings, which invited attacks from the rival coalition. Who would lead the coalition if it won? 'The party with the most seats', the Peoples' Coalition responded. Would that leader be a Fijian? The answer was the same. The coalition similarly had a flexible arrangement about allocating seats in the open constituencies. In some constituencies, it supported a common candidate, while elsewhere it fielded parallel candidates. Where it fielded parallel candidates, the coalition partners were given their second preference. This worked well for the most part, but created problems in some places. PANU, for example, expected to be allowed to field candidates in western constituencies with substantial Fijian population, but Labour disagreed and fielded its own, poaching some of Tora's own prominent supporters and potential candidates, among them Ratu Tevita Momoedonu. Tora's own seat was contested by Labour, whose candidate beat him. Outmanoeuvred, Tora refused to attend any of the People's Coalition rallies. Towards the end of the campaign, he became a vocal critic of the Labour Party, chiding Labour president Jokapeci Koroi for not forgiving Rabuka for his past actions and accusing Chaudhry of treachery (Fiji Times 7 May 1999). Tora refused to give preferences to his coalition partner, the Fijian Association Party, which had fielded candidates against his own. But by then, he mattered little. For once, the Machiavellian politician had been marginalised.

\section{Veitokani Ni Lewenivanua Vakaristo/Christian Democratic Alliance (VLV/CDA)}

This party was launched on 27 March 1999, on the eve of the election, by Fijians variously opposed to Sitiveni Rabuka and his government. Its support came from three sources. First, there were those who opposed the 1997 Constitution. Rabuka and his party had 'failed the Fijian people miserably', 11 the VLV charged. Rabuka had given away too much; he had 'exploited the indigenous Fijian institutions for his own glorification, even to the extent of selling out on the rights and interests of Fijians'. Unless the 'core interests' of the Fijians were addressed, there would be no political stability in the country. 
We remind the PM of the VLV's primary platform that unless there is stability in the indigenous Fijian community, there will be no stability in this country in the future. It will all be fruitless and a waste of effort for all who have been trying to build and make Fiji a better place for all to live in.

In essence, they wanted to restore those provisions of the 1990 Constitution which would have kept power in Fijian hands and given substance to the notion of Fijian paramountcy.

Other members and supporters came from sections of the Methodist Church which wanted to turn Fiji into a Christian state (see Daily Post 31 March 1999). The very public blessing given to the party by the affable but malleable president of the Methodist Church, Reverend Tomasi Kanailagi, and the presence within it of such fire-breathing figures as former president Manasa Lasaro and Taniela Tabu, was powerfully symbolic. These people wanted the Sunday Ban re-introduced, which reversed the stance the church had taken when Dr Ilaitia Tuwere was president in the mid 1990s. Tuwere had argued that turning Fiji into a Christian state could not 'make it a better place for everyone to live in. It will neither further the cause of Christianity nor adequately meet the present wish to safeguard Fijian interests and identity'. And attention to 'man's careless disregard of the environment was more urgent than Sunday observance' (Daily Post 31 March 1999). Much depends on the character and vision of the person at the helm of the church. Nonetheless, religion is close to the heart of many Fijians, and most would not oppose the Christian state proposal. But others wanted to manipulate this deep religious attachment for their own ends.

The VLV claimed the support of 'members of the chiefly establishment'. To prove it, they made traditional approaches to Ratu Mara (Tui Nayau) and Adi Lady Lala Mara (Tui Dreketi), as well as Tui Vuda Ratu Josefa Iloilo. Most people believed that the president silently supported the party. ${ }^{12}$ Close members of his own family were contesting the election on the VLV ticket, including his daughter and son-in-law, and Poseci Bune who was expected to 'strengthen and consolidate the Mara/Ganilau dynasty' (Daily Post 29 March 1999). Fairly or unfairly, the president was accused of harbouring dynastic ambitions. Many Fijians remarked on Mara's cool relations with Rabuka, and his desire to see the prime minister defeated. Many founding members of the Fijian Association were known to the president as members of the Diners Club formed in the early 1990s, with whom he shared his experiences and reflections on politics. Rabuka had defeated Lady Lala for the presidency of the SVT, which was not forgotten or forgiven. And Rabuka's claim, during the election and before, that he had been used to stage the coup, raised questions about who else was involved, including members of the chiefly establishment which now supported the VLV. Rabuka said that he was the fall guy who refused to 
fall. His comment, in Lau of all places, that a commoner candidate could be more accessible than a chiefly one, raised further questions about his loyalty to chiefs (Daily Post 7 May 1999). Mara's relations with Rabuka, never warm, had become decidedly chilly.

As the campaign proceeded, the VLV attempted to distance itself from extreme platforms, and proclaimed its commitment to socially progressive policies. These included reorganising and restructuring regional development, improving 'economic, social and human conditions in the rural areas,' and assisting the provinces to implement 'infrastructure plans and projects, industrial, business and commercial plans and projects, agriculture, forestry and fisheries plans and projects, and social/human development plans and projects', whatever these phrases, allegedly written in New York by an expatriate former Fiji public servant (Peter Halder) might mean, facilitating Fijian ownership of business, industry and commerce in each province and assisting Fijian landowners to 'utilise their lands for their own economic development and upliftment' (The Review April 1999). Bune, an experienced civil servant and former representative at the United Nations, got himself elected as party leader over Ratu Epeli Ganilau, the army commander who had resigned to contest the Lau open seat; but his elevation was contested by powerful party insiders who questioned his background and personal and moral credentials. ${ }^{13}$ Nonetheless, the VLV fielded some well known and experienced candidates, including Ganilau and Adi Koila Mara Nailatikau, Fijian academic Asesela Ravuvu, trade unionist Salote Qalo, and lawyers Kitione Vuataki and Naipote Vere.

Among the smaller Fijian parties, the Fijian Nationalist Vanua Tako Lavo Party was the most prominent. Led by longtime Fijian nationalist Sakiasi Butadroka, it was the latest reincarnation of the original Fijian Nationalist Party founded in 1975 to keep 'Fiji for the Fijians.' Twenty years later, it had changed little, except in name. The party rejected the 1997 Constitution as a sell-out of Fijian interests, and wanted Rabuka punished for betraying the aims of the coup which, they said, was to entrench Fijian political control. Its manifesto proclaimed that 'in addition to the normal guarantees for 75 per cent support from the Great Council of Chiefs for amendments concerning the Fijian people, we will ensure that 100 per cent support will be needed from all 14 Provincial Councils before any changes can be made to the iron clad guarantees affecting the Fijian people'. The name of the country would be changed from the Fiji Islands to Fiji because 'we want to be identified overseas as Fijians not Fiji Islanders' (Daily Post 16 April 1999). The Fijian language would be taught in all schools, Crown land returned to the indigenous people, and special bodies would be set up to exploit natural resources in the interest of the Fijian people. Fine words, but the party was now a caricature of its former self, not a force of consequence. Some leading members (including Isireli Vuibau) had joined other parties, 
while ex-Taukei Movement member Iliesa Duvuloco was embroiled in financial difficulties. After the elections, Butadroka changed his trademark blood-red bow tie signifying violence if Indians ever challenged Fijian right to rule, to a black bow tie, mourning the political loss 'of the Fijian race'.

\section{Issues}

For the SVT/NFP/UGP coalition, the main question was which party or coalition was best placed to provide political stability. Reddy spoke for the coalition

Experience around the world shows that political stability is a precondition for economic and social progress. Without political stability we will not be able to achieve anything. Political stability will lead to enlightened and progressive policies which, in turn, will generate business confidence, investment, economic growth and, above all, jobs for our unemployed..$^{14}$

The NFP had always been the majority party of the Indian community, while the SVT 'is without doubt the majority Fijian party representing the widest cross-section of the Fijian community', and the UGP was the largest party of the General Electors. This coalition, he said, broadly based, representative, and with a record of working together was 'best placed to provide that political stability which will form the foundation for progress on economic and social issues'.

The SVT paraded its achievements, reminding Fijians of its pro-Fijian activities: more scholarships for Fijians, financial assistance, the promise to revert crown land to Fijian landowners. It reminded them of the new hospitals and health centres in Kadavu, Lami, Nabouwalu, Rabi and Rakiraki, improvements in infrastructure, including better shipping services to the islands under the Shipping Franchising Scheme; completion of major bridges; rural electrification; improved water supply in rural areas; the poverty alleviation scheme ( $F \$ 4.4$ million per year), and better housing for low income earners. But these achievements did not impress the voters, who remembered the scandals which had brought the country into disrepute and close to bankruptcy. There was widespread suspicion that a chosen few and those well connected had done well, but not the bulk of the citizens. In western Viti Levu, opposition parties said publicly that their region had been neglected, as in the past, and that the bulk of the development projects had gone elsewhere.

The SVT claimed credit for 'wide consultation in the comprehensive review and promulgation of the new Constitution, which laid the foundation for a united, free and democratic multi-racial Fiji'. It claimed credit for Fiji's readmission to the Commonwealth, and for restoring Fiji's link with the British monarchy. The Fijian electorate was unmoved. Many 
thought that the revised Constitution had somehow whittled down the Fijian position and deprived them of rights. The government claimed credit for establishing the 'framework for a multiparty government', when most Fijians wanted a Fijian government with some participation from the other communities, not equal partnership. The opposition Fijian parties, with diverse agendas and ideologies, united to condemn the SVT for compromising Fijian interests.

Rabuka's firm and decisive leadership had indeed been instrumental in negotiating the Constitution, without which the outcome could well have been different. Even his closest colleagues in cabinet had opposed the report of the Constitution Review Commission, and had tried to have the Constitution amended at the last minute. Eight of the 14 Fijian provinces had rejected the report; for their elected leaders now to claim credit was difficult. The hero of 1987 had become the villain of 1999, deserted by close supporters and friends and high chiefs with agendas of their own. They all wanted him defeated.

The NFP praised Rabuka to skeptical Indian audiences as the leader best suited to take Fiji into the next millennium. ${ }^{15}$ Rabuka responded by apologising for the pain the coup had caused the Indo-Fijian community, and espoused an inclusive vision.

I believe we cannot build a nation by tearing people down. No matter how they arrived in Fiji, they are a part of Fiji society. This is their land to till and make productive. We owe it to the indentured labourers, to cotton planters for what we have now. Let us leave our differences aside, have common interests in our hearts to build a beautiful Fiji (speech in Labasa, 10 April 1999).

Rabuka appeared genuine in his contrition, but it came late, and in the heat of an election campaign sounded expedient. As one observer put it, 'commitment to multiracialism and forgiveness for sins past' sounded all too vague. 'It is feel-good politics that blisters under the blowtorch of the Fijian Association Party-Labour call for new direction' (Fiji Times editorial 3 May 1999).

For the NFP, the successful constitutional review and the promulgation of the new Constitution was the main platform in the campaign. Much had been achieved through dialogue and discussion with a mainstream Fijian party, and it promised to continue that approach. If the Indian people wanted to resolve the land lease issue, they could only do so with the support of the main party of the Fijian people. It urged voters to take a longer-term view. Much had been accomplished, but much remained to be done. The NFP praised Rabuka as the man who had risked his political capital among his own people. They acknowledged his past misdeeds, but as Reddy said, 'this is the same person who has shown, by leading the 
revision of the Constitution, that he believes in genuine multiracialism, not just in parliament but more importantly in Government' ${ }^{16}$ He continued

We are not in a partnership with token Fijians and General Voters, as in 1987, after which the coups took place. These parties will have the full force of their racial groups behind them. This Coalition will have real political authority and social backing to tackle the problems of our country, for example crime and ALTA (Reddy Final Campaign Speech 3 May 1999).

NFP wanted to eschew confrontational politics which 'only result in misery for people'. Instead, 'this is a time for moderation, reconciliation, and tolerance of all races, regions and cultures that grace this beautiful country of ours'. Reddy reminded voters of his party's record in opposition: 'The country knows that we have been in the forefront of bringing these issues (corruption, mismanagement of the economy, and inefficiencies) to the attention of the public, whenever the need has arisen'. Nonetheless, as Stewart Firth from the Fiji Times remarked, 'No answer could explain to an average Indian the reason why NFPleader Jai Ram Reddy formed a coalition with Sitiveni Rabuka's party' (Fiji Times 18 May 1999).

The NFP also made much of Labour's allocation of preferences. In 22 seats, Labour gave its first or second preferences to the VLV, a party whose policies were 'abhorrent, contrary to the spirit of our Constitution and against the interests of the Indian community' ${ }^{17}$ The VLV would reintroduce the Sunday Ban, make Fiji a Christian state and change the Constitution. The NFP placed the VLV last, and despite its competition with Labour it placed that party above the VLV 'as a matter of principle and morality'. For Labour, however, the election was not about principle and morality: it was about winning. To that end, it put those parties last which posed the greatest threat. Among these parties was the NFP, its main rival in the Indian communal seats. Labour's unorthodox tactic breached the spirit and intention of the preferential system of voting, where like-minded parties trade preferences among themselves and put those they most disagree with last. Political expediency and cold-blooded ruthlessness triumphed. Reddy was right about Labour's motives when he said that Labour wanted 'to get rid of Rabuka and the SVT [and Reddy and the NFP as well] at all cost'.

The Constitution, on which the NFP had placed such store, was for Labour an accomplished fact and a non-issue. It made no mention of it in the manifesto. When reminded, Labour belittled Rabuka's and Reddy's roles, saying that the Constitution was the work of the Constitution Review Commission and the Joint Parliamentary Select Committee. In any case, why should Rabuka be praised for rectifying a grievous mistake he had made in the first place. As Sir Vijay Singh put, 'in restoring the democratic Constitution', Rabuka 'did the Indians no favour'. He 'restored what he 
had stolen in the first place. He is deserving of some mitigation. If you were a criminal in court and you did some right thing, the court will deal with you lightly but it won't reward you' (fijilive 19 May 1999). It was a harsh, unforgiving judgement on Rabuka and what he had accomplished in the most difficult of circumstances and against powerful opposition from within his own party. Moreover, Rabuka was not alone in carrying out the coups. Some of Sir Vijay's own former colleagues in the Alliance Party (and now Rabuka's bitter opponents) had joined the colonel in 1987 to overthrow the 1970 Constitution. But these subtle points did not register.

Labour reminded the electorate of SVT's sorry record in government, and implicated the NFP in the mess, calling it the Rabuka-Reddy record: ${ }^{18}$ mismanagement of public office; corruption at the top echelons of government; alarming crime rates; high unemployment; enforced redundancies in public enterprises brought about by privatisation and corporatisation; a high cost of living in an economy deep in recession with two consecutive years of negative growth; and the dreadful infrastructure with clogged up river systems prone to flooding, rundown roads and disrupted water supplies. This, Labour said, was the true record of the SVT government. The electorate understood. The sight of redundant workers at Nadi airport while the election was in progress reinforced the image of the government as uncaring and arrogant. The NFP said little; for Labour the pictures of the redundant workers were a godsend. 'The NFP', Labour president Koroi remarked, 'has been an ineffective opposition, frequently actively supporting the repressive measures of a government whose sole aim is to remain in power permanently' (Daily Post 2 April 1999). The electorate believed her.

Labour also promised policies and initiatives of its own. It would remove the 10 per cent value-added tax and customs duty from basic food and educational items, review taxation on savings and raise allowances for dependents, provide social security for the aged and destitute, and lower interest rates on housing loans. If elected, Labour promised to repeal legislation requiring farmers to pay back the $F \$ 27$ million cash grant and crop rehabilitation loan made to drought-stricken farmers in 1998; establish a Land Use Commission, in consultation with landowners and tenants, to identify and access vacant lands; and oppose privatisation of strategic utilities such as water, electricity, telecommunications and civil aviation. 'We also believe that the overall control of the exploitation of natural resources such as forestry and fisheries must remain in State hands to maintain their sustainability. We will, therefore, reverse all moves to restructure and privatise them.'

Labour's partners broadly shared its policy platform, but their main target was Rabuka, for who he was and for the record of his government. The Fijian establishment, in whose name he had carried out the coup, 
jettisoned him as an ambitious commoner unfit to govern, a man who had overreached his authority and station. He had to be defeated almost at any cost. For Chaudhry, removing Reddy and his party was a major item.

\section{Results}

Voting in Fiji was compulsory for the 428,000 registered voters, but only 393,673 voted. Of the votes cast, 8 per cent were invalid. There were roughly equal numbers of invalid votes among Fijians ( 8.7 per cent) and Indo-Fijians (8.5 per cent). The percentage of Fijians not voting was slightly higher (10.9 per cent) than among Indo-Fijians ( 7.5 per cent). The Labour Party won 37 of the 71 seats in the House of Representatives, and thus was entitled to form a government in its own right. Its coalition partner, the Fijian Association Party, won 11, PANU 4 and the Christian Democrats 3. The UGP won 2 seats, the SVT 8 and, the biggest surprise, the NFP failed to win a seat. Fijian Nationalists won 2 seats and Independents 4 seats.

The Indian communal seats saw a two-way contest between Labour and the NFP. Labour won 108,743 of the 165,886 Indian communal votes cast (65.6 per cent of first preference votes) and the NFP 53,071 (32 per cent). Independents and other parties got 4,030 (2.4 per cent). Labour fared well in rural and urban constituencies, its electoral dominance evenly spread. Among the Fijian parties contesting the communal seats, the SVT won 68,114 or 38 per cent of (first preference) Fijian votes, VLV 34,758 (19.4 per cent), Fijian Association Party 32,394 (18 per cent), PANU 17,149 (9.6 per cent), Independents 7,335 (4.1 per cent), Nationalist Vanua Tako Lavo Party 16,353 (9.1 per cent) and Labour 3,590 (2.0 per cent). Labour's poor performance among Fijians should be seen in context. Although it fielded some Fijian candidates, Labour left Fijian constituencies largely to its Fijian partners. When the votes in the open seats are taken into account, there is evidence of large Fijian support for the party. There, of the 360,085 valid votes cast - 428,146 were registered of whom 393,673 voted-Labour won 33.3 per cent of the votes, SVT 21 per cent, VLV 9.8 per cent, NFP 14.4 per cent, Nationalists 4.2 per cent, Fijian Association Party 10.8 per cent, Independents 2.1 per cent, United General Party 1.3 per cent and PANU 2.7 per cent.

Among General Voters, 11,981 voted from a total of 14,029 . That is, 14.6 per cent did not vote and of those who did, 8.2 per cent were invalid. The United General Party won 5,388 votes (49 per cent), Fijian Association Party 1,052 (9.6 per cent), Independents 3,346 (30.4 per cent) and the Coalition of Independent Parties 1,156 (10 per cent). The strong support for Independents centered on personalities (Leo Smith and Bill Aull who were prominent sitting parliamentarians).

Why the massive swing to Labour? The NFP argued that Indian voters had taken revenge for the coups, that its pre-election coalition with Rabuka 
cost them the election. If NFP had not allied itself with the SVT and not revealed its hand, it would not have carried SVT's baggage. It would then have been able to mount an effective campaign in its traditional constituency and win enough seats to become a player in parliament. There is a grain of truth in this assertion. Certainly Labour advertised its campaign as a continuation of a brutally interrupted experiment of 1987, with Dr Timoci Bavadra's official portrait adorning many a campaign shed in western Viti Levu. Rabuka's public apologies unwittingly revived memories of disrupted careers, lost incomes and broken lives. The NFP's pre-election coalition may have cost it votes, but would an alternative strategy have made much difference?

The answer is not at all clear. In the public mind, Reddy was already hitched to Rabuka through the constitutional review, and any attempt by the two leaders to distance themselves from each other, after having worked so closely for so long, would have been hugely counterproductive for the politics of moderation and reconciliation they were preaching. Labour would not have left Reddy alone over Rabuka. They would have prodded and provoked and demanded to know why Reddy was not with the SVT leader. On the other side, the Fijian nationalists, unhappy with the new Constitution, would have accused Reddy of treachery, and of using Rabuka and the Great Council of Chiefs to amend the Constitution to suit the interests of his own community. The Fijian supporters of the SVT would have felt used and discarded.

Reddy argued that his party had taken the correct decision to ally with the SVT. The Coalition, he said

was based on some very fundamental principles. And you don't abandon your coalition partners because they have done something wrong or they may be suddenly becoming unpopular. But I didn't see it that way. I saw the SVT as the mainstream Fijian party. They were founded by the chiefs. They seemed to have the support of the Fijian people. The important thing is that all these things we did with the utmost good faith. We did it because we believed in something. We believed that Indian and Fijian people and everybody else must be brought together in government (The Review June 1999).

He had been honest with the electorate. His coalition decision was not 'a grievous error of principle as well as strategy', ${ }^{19}$ as some commentators noted, but a principled and courageous one.

The NFP's problem lay not so much in the message as in its failure to take it effectively to the voters. In hindsight, its focus on the Constitution, the great achievement that it was, to the virtual exclusion of any other issue was probably a mistake. Selling an untried Constitution, however good, to a skeptical, suffering electorate was not the same as criticising a 
demonstrably flawed one, as it had done successfully in 1992 and 1994. The fact that it could not use its solid performance as an opposition party, now that it was in partnership with the party in government, weakened its campaign. In short, the NFP was caught in a trap. A frontal attack on the SVT would have polarised the main communities, revived the hostilities and taken the country back to the tired politics of ethnic confrontation.

Labour's message was sharper and more effective, its criticism of government relentless. Its focus on bread and butter issues of employment, better health, social welfare and an accountable government, sat well with the electorate. Moreover, it had an extensive network to communicate that message. The Fiji Public Service Association, of which Mahendra Chaudhry was the head, covered the public sector unions. The National Farmers Union, of which Chaudhry again was the head, galvanised the farming community. And the Fiji Teachers Union, headed by Pratap Chand, a Labour candidate, reached out to primary and secondary teachers who play a pivotal social role in the community. They shape opinion and influence events. Farmers, workers and teachers were thus covered. The NFP's structure was less focused. Its once powerful working committees had become moribund, its decision-making and consultative function taken over by the Management Board. This change made the party more businesslike, but damaged its links to the grassroots.

Labour appealed to people who were desperate, and direct victims of government policies - 400 redundant employees at the Civil Aviation Authority, 15,000 garment factory workers and their families, squatters and residents of low-cost Housing Authority flats, people threatened with job losses at the Fiji Electricity Authority, Telecom Fiji, the Fiji Sugar Corporation and in the public service, already reeling from the 20 per cent devaluation of the Fijian dollar. The NFP's appeal lacked focus. The Indo-Fijian community, whose interests it sought to protect, was increasingly divided in its interests and aspirations. The middle class, a constituency traditionally receptive to its message of gradual progressive change and with a keen eye on investment in a long term future, has been declining through migration. Over 70,000 have left since the coups while Labour's base of workers, farmers and teachers remained intact. For them, the immediate social and economic concerns were more important than saving for a rainy day. As one observer put it, the NFP achievements on the Constitution and talk of racial harmony were abstract issues while Labour promised tangible gains' (The Review June 1999), reducing prices, increasing exports, creating jobs. The NFP was perceived as a rich person's party, uncaring about the concerns of ordinary people. ${ }^{20}$

In the sugar belt, the heartland of the Indo-Fijian community, Labour outmanoeuvred the NFP. The National Farmers Union had displaced the NFP-backed Fiji Cane Growers Association as the most effective voice of 
the farmers. Ironically, it was the NFP which had paved the way for Chaudhry's entry into sugar politics after the coups, handing over to him a constituency that had long been the party's own but which Chaudhry would convert into his own solid base. To the drought-stricken farmers, Labour promised relief and concrete proposals: addressing the problem of milling inefficiencies, improving the transportation system, exploring diversification into agro-based industries, and writing off the $F \$ 27$ million crop rehabilitation loan. Labour told the farmers that Reddy had opposed the cash grant, which patently misrepresented his position. The NFP cried foul, but the damage was done. The sugar belt turned to Labour as never before.

Rabuka's defeat was caused by several factors. His government's scandal-ridden performance was one. For many ordinary Fijians, life had not improved much since the coups. As Tamarisi Digitaki put it

At the grassroots level, the standards of living have remained largely unchanged from ten years ago. While his [Rabuka's] government's performance on the national and international fronts has been commendable, it is in the rural areas that the goods have failed to be delivered. Poor roads, water supply, communication services, education facilities and shipping services to the islands only give rural people more reason to vote the government out of office (The Review February 1998).

Rabuka conceded that the complacency of his parliamentarians and a dormant party structure cost him votes, saying that 'while party leaders were busy resolving national issues, no one was really looking into bread and butter issues affecting its supporters. ${ }^{21}$ Labour and its partners capitalised on this rural disenchantment.

Rabuka's pursuit of moderate, conciliatory politics was always going to risk being outflanked by more extremist parties. Parties which court moderation in a multiethnic society tempt fate. Rabuka was accused of selling out Fijian interests, just as Reddy was accused of playing second fiddle to the Fijians. Further, Rabuka was not fully in command of his party. The 23 Fijian seats are contested on provincial lines, and candidates are selected in consultation with provincial councils. In some cases, candidates preferred by the party were overruled by the provincial councils, an example being the replacement of the highly regarded Education Minister Taufa Vakatale by Jone Kauvesi for the Lomaiviti Fijian seat. Provincial concerns and interests take priority over party. These problems of divided loyalties will plague Fijian politics as long as elections are fought from within provincial boundaries.

Rabuka also suffered from deserters from his camp. These included leaders of the Methodist Church, like Manasa Lasaro, Viliame Gonelevu 
and other earlier supporters. Now they had formed a party of their own, the VLV, which repudiated Rabuka's policies and accused him of being a traitor to his people. Joining them were opportunists like Poseci Bune and Asesela Ravuvu. Compounding Rabuka's trouble was the disdain of leading chiefs who were 'uncomfortable with a commoner being in power' and who believed that 'Fijian leadership should always remain with the chiefs' (The Review June 1999). Ratu Mara's disparaging assessment of Rabuka was no secret, fueled, it was said, by envy at Rabuka's success in getting the Constitution through parliament and his increasing national and international stature, as well as Ratu Mara's dynastic ambitions. Rabuka's anti-chiefly remarks, while appreciated by commoners, infuriated powerful chiefs, Ratu Mara among them.

The political fragmentation of Fijian society has distressed many Fijians, and Rabuka regarded this as a major causes of his defeat. 'Gone are the days when Fijians worked in accordance with what was required of them from their elders. Now when an order is given from an elder, they are asked to give the reason and if they are satisfied, then they can act' (Daily Post 27 March 1999). He was referring to the influence of urbanisation, multiracial education and the challenges and opportunities of a multiethnic society. The use of the provincial boundaries for electing members to parliament accentuated provincial rivalries and sentiments, to the detriment of a centralised party structure. The decline in the number of Indo-Fijians through emigration and a lower birthrate diluted the fear of Indian dominance, which fostered Fijian political unity. Finally, the absence from the national stage of strong and powerful chiefs-a Ratu Mara or Ratu Penaia or Ratu George and Ratu Edward Cakobau-opened up opportunities for others. It is unlikely that Fijian society will see the likes of these on the national stage in the near future.

\section{The race to be prime minister}

As the count proceeded and a change of government appeared likely, most people wondered what Rabuka's next move might be. The defeated SVT leader conceded defeat with exemplary grace and dignity. His words are worth recalling not only because of their symbolic importance but also as a measure of the man Rabuka had become. The people of Fiji had demonstrated to themselves and 'to the watching world that we have embraced democracy fully by the way the election was held and by the very nature of the result'. He congratulated the Labour Party, and told his supporters: 'Take heart that we have fought the good fight. We have given all that we could. Let us now, without rancour and bitterness or any sort of division, congratulate our fellow citizens who have won the day.' Rabuka lamented the apparent block voting by the Indo-Fijian community, but urged the new government to 'govern us all'. He would lend support when 
necessary, promising to be 'vigilant to ensure a just, accountable and honest government'. He urged the people 'to move to the centre ground, the middle ground', to 'genuinely come together to work for the common good of all our people'. It would be a terrible tragedy to 'dismantle the progress that we have made together'. Rabuka thanked Reddy for his support. Reddy knew the risks he was taking in coalescing with his party, but as a leader with 'deep conviction and strong principles, he courageously stuck to our agreement and it has cost him and his party dearly'. Not all was lost. 'I now give my assurances to him and his loyal supporters that their sacrifice and contribution in helping to lay the framework for lasting national unity, stability and progress in our country has not been in vain.'

To the Fijian people, he said

We must find a way to come together to allow our collective voice to be heard. And to be a force in shaping the future of our country. We have allowed ourselves to splinter into different groups working against our common interest. We know the wise words that a house divided amongst themselves cannot stand. We have a lot of houses, our collective yavu and vanua have become divided. And the result is our voice in Government has been diminished (radio broadcast, typescript in my possession).

Rabuka promised to keep a watchful eye on the government, but before parliament met, he resigned his seat. In a stunning move, Rabuka then got elected chair of the Great Council of Chiefs by polling-the first time in history that chiefs had used secret ballot-32 votes to Tui Vuda Ratu Josefa Iloilo's 18. Rabuka described his victory as 'a sign of the chiefly support I have' (Daily Post 5 June 1999). His name was moved by Adi Litia Cakobau from the leading chiefly family of the Kubuna confederacy and seconded by Ratu Tevita Vakalalabure, the Vunivalu of Natewa.

Labour's victory put Chaudhry in the driver's seat. Within hours of the election results becoming known, Chaudhry convened his Labour parliamentary caucus which elected him as the party's nominee for prime minister. Soon afterwards, he was appointed prime minister by Ratu Mara. Chaudhry's other coalition partners were not consulted or informed, and they reacted angrily, claiming Chaudhry's appointment a breach of an implicit agreement to have an ethnic Fijian as prime minister. Adi Kuini Bavadra Speed, the Fijian Association leader, asked Mara, through Ratu Viliame Dreunimisimisi, to revoke his decision and appoint her as head of government because she was the leader of the largest 'Fijian' party in the winning coalition. Poseci Bune, the VLV leader, began canvassing the possibility of heading a broad coalition of Fijian parties in opposition. Tora threatened to pull out of the coalition altogether. The Fijian Nationalists proposed to march against the government. 
Nothing happened. Chaudhry offered Speed the post of deputy prime minister which she accepted after Mara asked her to support Chaudhry, and after Labour threatened to invite the VLV into cabinet. Speed capitulated, quoting Mara's advice: 'It was basically appealing to us as leaders to consider the importance of cooperation rather [than] be at loggerheads with the new government' (Fiji Village 19 May 1999). Speed had been out manoeuvred. She could sit on the opposition benches with Rabuka, possibly as leader of the opposition, or become deputy prime minister. She chose the latter. Speed also opposed the VLV's inclusion in the cabinet, but was overridden. It was widely believed, but difficult to prove, that Mara wanted Bune and Adi Koila Nailatikau in the cabinetand that might have been the reason for his surprisingly warm public support for Chaudhry. Be that as it may, both were offered and both accepted cabinet posts, as did members of PANU, despite Tora's objections. Later, Chaudhry praised Mara for his critical role in getting the Fijian dissidents to support his government. In truth, Mara did what the Constitution obliged him to do: to appoint as prime minister the member of the House of Representative who in his opinion commanded majority support. Chaudhry's numbers bolstered his position: he was unassailable; he could govern on his own. But a confluence of interests brought Mara and Chaudhry together. The eastern chiefly establishment had felt ignored by the Rabuka administration; it was now in a position to be represented in cabinet. Mara's waning influence was also reinvigorated. For Chaudhry, the president's daughter in cabinet, and Mara's public support for his government, shored up Labour's credibility among Fijians who might otherwise have distrusted an Indo-Fijian prime minister. Dislike of Rabuka brought the men together: my enemy's enemy is my friend.

In his first broadcast as prime minister, Chaudhry was at pains to emphasise his government's broad non-racial appeal. He stressed repeatedly that he was prime minister 'not for any[one] community' but 'for everybody'. He pledged his commitment 'to complying with the requirements of the Constitution for the equitable participation of all communities in government', promising to 'ensure that all communities fully benefit from the nation's economic development'. He would be 'guided by the wisdom and counsel [of the Great Council of Chiefs] on all matters affecting the interests and welfare of indigenous Fijians and Rotumans'. The business community too had nothing to fear. 'In working to uplift the conditions of life of the poor, the workers, and the less privileged in our society we are not being anti-business. We're just being pro-people.' His government believed in development with justice 'but we are equally committed to laying down economic policies that will encourage investors and business to grow' (Address to the nation 19 May 1999). 
Chaudhry acted astutely in forming his cabinet. Eleven of the 17 ministers were ethnic Fijians, a gesture of reassurance to the Fijians that their interests were adequately protected. However, he himself controlled the key portfolios of Finance, Public Enterprises, Sugar Industry and Information. His Labour ministers controlled Foreign Affairs, Education, Labour and Industrial Relations, Commerce, Business Development and Investment, National Planning, Local Government, Housing and Environment, Justice, Regional Development and Multiethnic Affairs and Women, Culture and Social Welfare. Chaudhry knows that his success at the next election depends on his handling of the domestic social and economic agenda. People reacted cautiously and approvingly, though some Fijian nationalists as well as some defeated SVT parliamentarians wanted to oust Labour from power (Daily Post 28 May 1999). Rabuka was approached by people within his own party, including former senior ministers, to lead a 1987-style coup, but he rejected their overtures outright. ${ }^{22}$ Things had changed: the majority of the Fijian people had rejected the SVT, and the overwhelming sentiment in the country was to give the new government a chance to prove its mettle.

Fijians would not be fooled again, a searching editorial in a Fijian newspaper wrote (Volasiga 31 May to 6 June 1999). It was typical of the reaction throughout the country.

Sakiasi Butadroka and supporters of the Nationalist Vanua Tako Lavo Party are being mischievous and misleading in trying to scare the Fijians into believing the Indians have taken over Fiji...Buta is saying Ratu Mara and Mahendra Chaudhry are selling the rights of the indigenous Fijians. But we all know that no one on their own can sell the rights of the Fijians. No one who is not a Fijian, even if he or she is head of the Government, can remove the rights of Fijians to their land and resources. This will only happen if the Fijians themselves agree to it.

The editorial then drew attention to the problems facing the Fijian people which, it added, had little to do with other groups. 'When we look at our schools and their academic results, we see it is mainly the Fijians who are failing their exams. That's because there are weaknesses in our family life and within Fijian society.' The majority of those breaking the laws were Fijians. The biggest victims of sexually transmitted diseases were Fijians. Teenage pregnancies and single mothers were disproportionately Fijians. 'Who then is Butadroka fooling in Fiji? We are trying to catch up on the difficulties in life we are now facing and to reverse the general opinion that we are lagging behind.' To many Fijians, then, Chaudhry was not an adversary but an ally. It was their own leaders, drunk on power and dulled into complacency, who had deserted them.

Parliament opened on 15 June 1999. In his opening address, the president outlined the government's policies for its first term. The government's 'two 
crucial and central challenges' were to 'further strengthen the bonds of unity in our multiethnic and multicultural society' and to 'promote economic growth and social progress'. These challenges, said Mara

are to be undertaken with a strong sense of social justice to ensure that development benefits all in our society, including the poor, the disadvantaged and all those who, through no fault of their own, need the helping hand of the State. Government will implement affirmative action and social justice programs to secure for all citizens and communities equal and equitable access to opportunities, amenities and services to better their lives.

How these appealing but uncosted promises were to be honoured would be watched carefully. The promises were impressive: removing value-added tax on basic food items, medical charges and supplies and essential educational items; establishing a minimum national wage scheme; providing social security for the elderly and removing the user-pay concept in health care; introducing a national health service; establishing a bank to service the farming community; reducing the cost of public utilities; establishing a land use commission to identify and access vacant land; upgrading equipment at the four sugar mills and building new ones in Sigatoka and Seaqaqa; revitalising and diversifying agriculture; and making investment capital and other inputs available to entrepreneurs at a reasonable cost. The Chaudhry administration delivered on some of its promises. The F\$27 million loan repayment for crop rehabilitation was waived. The Rabuka government's privatisation of strategic public assets was halted. The prime minister insisted on more effective performance from his senior public servants. He has also ordered that all interest rates with banks and Housing Authority and Home Finance be decreased from 12 per cent to 6 per cent. But there was a long way to go.

Chaudhry made a concerted effort to assure the Fijian community that he would not undermine their interests. Soon after the election, he addressed the Bose Levu Vakaturaga; only the second Indo-Fijian (after Jai Ram Reddy) to do so, seeking their blessing and expressing his gratitude 'for their immense contribution in laying the foundation for freedom, democracy, unity and development in our country' (Ministry of Information Press Release 8 June 1999). His government agreed to honour a request by the BLV to transfer all state Schedule A and Schedule B land to the Native Land Trust Board. The decision was widely praised in the Fijian community. The government also pledged to continue the special annual education fund of $\mathrm{F} \$ 4.5$ million for Fijian education, and initiated programs to ensure that people on remote islands were 'not denied the benefits of development'.

It was not all plain sailing. There was hope of a long road ahead to translate a vision into reality. Fate willed otherwise. 


\section{Notos}

I thank Donald Denoon, Stewart Firth, Padma Lal, Ron May, Robert Norton, Joeli Veiyataki and Christine Weir for their helpful comments which improved both the readability as well as the substance of this chapter. To Dilip Khatri, Davendra Nandan, Surend Prasad and Prem Singh of Nadi, Fiji, I owe many a conversation on the campaign trail which lightened the burden of research and forged friendships which will endure. None of them are responsible for my errors of judgment and facts.

1 For an overview of these periods, see $\operatorname{Lal}(1992,1998)$.

2 See Fiji Constitution Review Commission (1996). A summary of the work of the Commission is provided in Lal (1997).

3 The words are from the Pacific Report 10 May 1999, but they are echoed in virtually every newspaper overseas and in Fiji. Fiji's most respected journal, Islands Business, even went on to predict the composition of the next Rabuka-led government.

4 The 52-seat house provided for by the Independence Constitution had 27 communal (racially-reserved seats, 12 each for Fijians and Indians and 3 for General Electors) and 25 cross-voting seats (10 each for Fijians and Indians and 5 for General Voters). The ethnicity of the candidate was specified, but all voters voted for them.

5 These were the Fiji Labour Party, National Democratic Party, National Federation Party, the Soqosoqo ni Vakavulewa ni Taukei, Fijian Association Party, General Voters Party, General Electors Party, Vanua Tako Lavo Party, Vitilevu Dynamic Multiracial Party, Party of National Unity, Veitokani ni Lewenivanua Vakaristo Party, United National Labour Party, Party of Truth, Natural Law Party, Coalition of Independent Nationals Party, Nationalist Vanua Tako Lavo Party, Farmers and General Workers Coalition Party, and Lio 'On Famor Rotuma Party.

6 ALTA was negotiated in the late 1960s under which tenants were given 30 year leases of native Fijian land. These leases have begun to expire. Landlords want their land back, placing the mostly Indo-Fijian tenants in a precarious position. Balancing the interests of tenants and landlords is perhaps the most thorny issue in Fiji at the moment.

7 For a study of the 1987 elections, see Lal (1988).

8 See The Review, March 1999: 'Divided they fall: selection of candidates split the General Electors'.

9 For more on this and the 1992 elections, see Lal (1993).

10 I owe this apt description to Robert Norton.

11 All the quotations in this section come from the party's campaign literature.

12 When he was confronted with this allegation, Ratu Mara reportedly replied that his 'conscience was clear'.

13 Among them, Colonel Inoke Luveni and Manasa Lasaro. They argued that Bune did not meet any of the criteria the party had laid down for leadership. These stipulated that the leader must come from a chiefly family and should be the offspring of a marriage; must not be divorced or separated from his wife and have a stable and happy family, and not have 'produced children' outside of marriage; be a Christian and a regular churchgoer, and must believe that Fiji should become a Christian state and that the Sunday Ban be reimposed. See Daily Post, 21 April 1999. 
14 From Reddy's final campaign address, 3 May 1999.

15 As claimed by NFP's Dr Wadan Narsey (comments made in Labasa on 10 April 1999).

16 From Reddy's opening campaign speech. The quotations in the following two paragraphs also come from it.

17 From Reddy's closing campaign address, 3 May 1999.

18 This is based on the People's Coalition Manifesto.

19 Among them Sir Vijay Singh, former Alliance government minister and now a regular columnist for a local daily. See Fiji Times, 18 May 1999.

20 Reddy acknowledged this perception in his first post-coup press conference, but he saw this 'partly [as] the result of very successful propaganda', noting that in recent years, his party had extended its base to include as candidates trade unionists, teachers, and women.

21 Interview in The Review, June 1999; see also Daily Post, 21 May 1999.

22 Personal communication with Rabuka. 